\title{
ZINC IN THE CAT PROSTATE
}

\author{
ELIZABETH AUGHEY \\ University of Glasgow Veterinary School, Glasgow
}

(Received 2nd April 1969)

\begin{abstract}
Summary. Chemical analysis of adult cat prostate shows that zinc is present in significant amounts. Attempts to demonstrate the zinc at cell level using dithizone give indeterminate results. From autoradiographs, the zinc is scattered throughout the cell but concentrated in the apical area, along the luminal surface, and free in the lumen. Electron micrographs of the acinar cell show secretory granules agreeing with the grain distribution of the autoradiograph. Previous histochemical findings gave a similar position for non-specific acid phosphatase and 5-nucleotidase. It is suggested that zinc is an integral part of the secretion of the cat prostate, and associated with the production of metalloenzymes.
\end{abstract}

\section{INTRODUCTION}

Zinc is present in the prostate of man (Bertrand \& Vladesco, 1921), the dog (Bartlett, 1958), the rat (Mawson \& Fischer, 1952) and many other animals in relatively high concentrations, but its physiological significance remains obscure. Zinc is known to exist in many metallo-enzymes ( $\mathrm{Li}, 1966)$, some of which have been reported to occur in the prostate, e.g. carbonic anhydrase, non-specific acid and alkaline phosphatase, and 5-nucleotidase (Mann, 1964). Non-specific acid phosphatase and 5-nucleotidase are present in the secretory epithelium of the cat compact prostate in which, therefore, zinc is to be expected (Aitken \& Aughey, 1964; Filotto, 1965); moreover, chemical analysis of cat prostate (conducted in the Department of Animal Husbandry, Glasgow University Veterinary School) revealed a high concentration of zinc ( 7.7 to 8.1 $\mathrm{mg} \mathrm{Zn} / \mathrm{g}$ ash).

It was proposed, therefore, to determine the distribution of zinc in cat prostatic cells, and, if possible, its association with the secretory granules by histochemical, autoradiographic and ultrastructural methods.

\section{MATERIAL AND METHODS}

Six, entire, healthy, adult, male cats of indeterminate age and breed were used.

\section{Histochemistry}

The histochemical detection of zinc depends on its chelation by diphenylthiocarbazone (dithizone) to form a pink complex (Mager, McNay \& Lionetti, 
1953). Small blocks of compact prostate were fixed in chilled methanol, processed, and embedded in paraffin. The sections cut at $5 \mu$ were treated with the dithizone and mounted in DPX.

\section{Autoradiography}

A solution of ${ }^{65} \mathrm{ZnCl}_{2}$ containing $1 \mathrm{mc}{ }^{65} \mathrm{Zn} / \mathrm{ml}$ was made up to $5 \mathrm{ml}$ with normal saline, giving a specific activity of $200 \mu \mathrm{c} / \mathrm{ml}$. One millilitre of the diluted solution was injected subcutaneously on each of 2 consecutive days; on the following day (Day 3), the cat was killed by an overdose of barbiturate and the compact prostate removed, fixed in absolute methanol at $4^{\circ} \mathrm{C}$ for $2 \mathrm{hr}$, cleared and embedded in paraffin. Sections were cut at $5 \mu$ and de-waxed with xylol.

Sections were covered with a solution prepared by dissolving a few strips of Ilford L4 nuclear emulsion in an equal amount of distilled water in a water bath at $40^{\circ} \mathrm{C}$ and exposed for 15 days, 1 month and 2 months, respectively. After exposure, the film was developed and fixed, the sections were counterstained lightly in haematoxylin and mounted in DPX. Alternate sections without emulsion served as controls.

\section{Ultrastructure}

Blocks of prostate (approx. $1 \mathrm{~mm}^{3}$ ) were fixed in cold buffered paraformaldehyde (Peters \& Palay, 1966), then placed in 1\%, cold buffered osmic acid, processed, and embedded in Araldite (Luft, 1961). Thick sections $(1 \mu)$ were cut and stained with toluidine blue (Ito \& Winchester, 1963) and the blocks were trimmed; ultra-thin sections were cut on an LKB ultratome, stained with lead acetate or uranyl acetate and viewed on a Siemen's Elminskop.

\section{RESULTS AND DISCUSSION}

The histochemical reaction from the dithizone-treated sections gave indeterminate results; in some cells, a fine granulation was seen throughout the cytoplasm, occasionally concentrated in the supranuclear part of the cell along the luminal surface (Pl. 1, Fig. 1). As a control of technique, sections of dorsolateral prostate from adult male rat were treated with dithizone simultaneously with the above. In these, the typical pink granulation of the apical cytoplasm was obtained (Gunn \& Gould, 1956; Rixon \& Whitfield, 1959).

Autoradiography gave a more precise localization of zinc in the secretory

\section{EXPLANATION OF PLATE 1}

FIG. 1. Illustrates the dithizone reaction of the prostate cell in the cat. Fine granulation (G) of the basal area of the cell can be seen and the concentration of grains along the luminal surface of the cell. $\times 225$.

Fig. 2. Autoradiograph after 1 month's exposure to show the grains (arrowed) along the luminal surface of the secretory cell and scattered throughout cytoplasm. $L=$ lumen of the tubule; $\mathbf{N}=$ nucleus. $\times 600$.

FIG. 3. The grains (arrowed) are mainly extra-cellular in this autoradiograph, and form the secretion of the prostatic acinar cell. $\times 600$.

Fic. 4. Electron micrograph of the apical area of a prostate cell to show microvilli, the secretion granules (arrowed) in the lumen of the tubule and within the cytoplasm. $\times 2500$. 
PI.S'IE 1

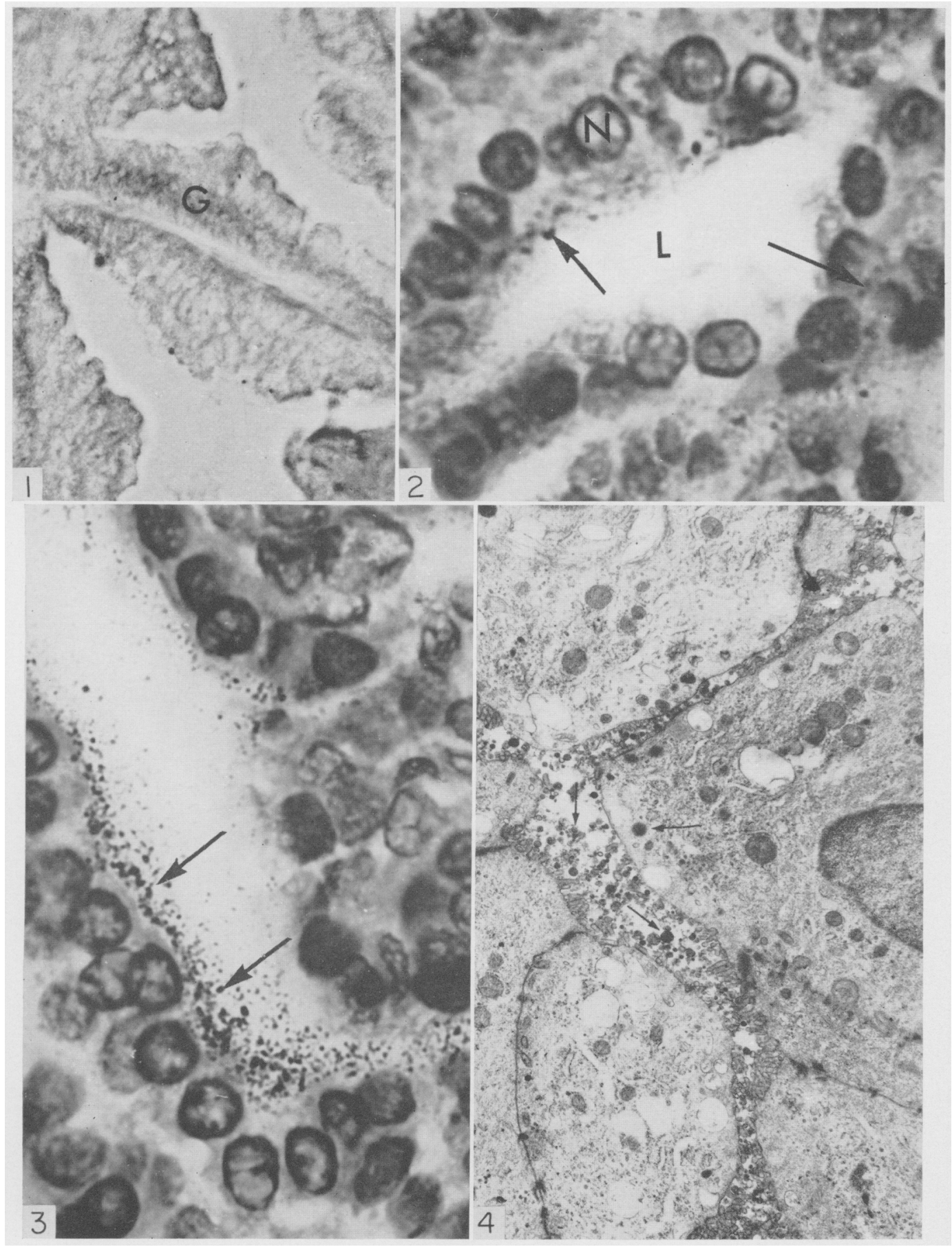


cell. After 15 days' exposure, a few silver grains were seen diffusely scattered throughout; some grains were found in the lumen of the gland tubule. After 1 month's exposure, the majority of the grains were dispersed along the luminal surface of the cell; some were scattered throughout the cytoplasm with occasional grain concentration over the nucleus (Pl. 1, Fig. 2). A proportion of grains were found free in the lumen immediately adjacent to the surface of the secretory cell (Pl. 1, Fig. 3).

In electron micrographs of cat prostate, numerous small secretory granules are visible in the luminal cytosome and in the gland lumen in the vicinity of the cell surface, many being found amongst the microvilli which project from the latter (Pl. 1, Fig. 4). The small secretory granules thus correspond to the location of the silver grains in the autoradiographs (Pl. 1, Figs. 2, 3).

The presence of zinc at all levels in the prostatic secretory cells, its concentration towards the luminal surface and its appearance in the lumen suggest that zinc is an integral part of the prostatic secretion in the cat. This is supported by the similar location of secretory granules in the luminal cytoplasm and in the lumen itself in electron micrographs of cat prostate. Aitken \& Aughey (1964), showed a similar location of acid phosphatase, 5-nucleotidase and secretory protein and it is suggested that zinc is secreted by the cat prostatic cells as a metallo-enzyme.

Repeated attempts to demonstrate zinc by histochemical methods in this species have invariably been inconclusive, indeterminate results contrasting sharply with the well-defined localization characteristic of autoradiographs. This discrepancy is not explained; the more precise localization, using this method, in rat tissue may be a function of the greater concentration of prostatic zinc in this species $(15 \cdot 2 \mathrm{mg} / \mathrm{g}$ ash; Mawson \& Fischer, 1951).

\section{ACKNOWLEDGMENTS}

I am indebted to Miss Gracie for technical assistance, Mr A. Finnie for the photographs, Mr J. Fryer of the Ghemistry Department for the use of the Siemens Elminskop, and to Mr R. N. C. Aitken for criticism of the manuscript.

\section{REFERENCES}

Aitken, R. N. C. \& Aughey, E. (1964) A histochemical study of the accessory genital glands of the male cat. Res. vet. Sci. 5, 268.

BartLetr, D. J. (1958) Biochemical characteristics of dog semen. Nature, Lond. 182, 1605.

Bertrand, G. \& Vladesco, M. R. (1921) Intervention probable du zinc dans les phénomènes de fécondation chez les animaux vertèbres, C.r. hebd. Séanc. Acad. Sci., Paris, 173, 176.

Filotro, U. (1965) Contributo allo studio della prostata di Felis catus. Osservazioni istochimiche. Atti Soc. ital. Sci. vet. 19, 346.

Gunn, S. A. \& GouLD, T. C. (1956) Differences between dorsal and lateral components of the dorsolateral prostate of rat in $\mathrm{Zn}^{65}$ uptake. Proc. Soc. exp. Biol. Med. 92, 17.

Ito, S. \& Winchester, R. J. (1963) The fine structure of the gastric mucosa in the bat. 7. Cell Biol. 16, 541.

LI, T. K. (1966) Functional role of zinc in metallo-enzymes. In: Zinc Metabolism, p. 48. Ed. A. S. Prasad. Charles C. Thomas, Springfield, Illinois.

LuFT, J. H. (1961) Improvements in epoxy resin embedding methods. F. biophys. biochem. Cytol. 9, 409. Mager, M., McNay, W. F. \& Lionetti, F. (1953) The histochemical detection of zinc. F. Histochem. Cytochem. 1, 491. 
MANN, T. (1964) The biochemistry of semen and of the male reproductive tract, p. 161. Methuen, London.

Mawson, C. A. \& Fischer, M. I. (1951) Zinc content of the genital organs of the rat. Nature, Lond. 167, 859.

Mawson, C. A. \& Fischer, M. I. (1952) Carbonic anhydrase and zinc in the prostate glands of the rat and rabbit. Archs Biochem. 36, 486.

Peters, A. \& Palay, S. L. (1966) The morphology of lamina A and A1 of the dorsal nucleus of the lateral geniculate body of the cat. 7. Anat. 100, 451.

Rixon, R. H. \& Whitfield, J. F., JR (1959) The histochemical localisation of zinc in the dorso-lateral prostate of the rat. $\mathcal{F}$. Histochem. Cytochem. 7, 262. 